\title{
LISENSI MEREK DALAM PERSPEKTIF PERKEMBANGAN BISNIS
}

\author{
Oleh: \\ Zudan Arif Fakrulloh*
}

A. Pendahuluan

Dalam perspektif bisnis, lisensi merupakan salah satu teknis pemasaran untuk membantu perkembangan bisnis lokal. Adapun keuntungan lisensi sebagai teknis pemasaran dibanding dengan teknik pemasaran lainnya adalah pada standart mutu produksi, menghemat waktu dalam pengembangannya, penghematan modal atau biaya investasi, peluang laba lebih besar dan faktor resiko lebih dapat Ejerkecil, karena dalam hal kekurangan modal dapat ditutup Aengan penjualan sensi produknya kepada yang berminat.

Sistem lisensi di indonesia mengalami perkembangan yang cak-ep pesat. Adapun penggunaan merek dengan lisensi banyak kita jumpai

zadis perlengkapan kebutuhan sehari-hari seperti makanan, obat-obatan, kosmetik, gukaian parfum, alat-alat rumah tangga, zuhan-bahan dan alat-alat bangunan, dan in-lain.

Sistem lisensi dapat dikatakan sebagai uhaikan dari sistem pengembangan bisnis ng menggunakan cara penanaman modal secara langsung atau kata lain lisensi adalah suatu terobosan bisnis terhadap ketentuan penanaman modal asing di Indonesia. Adapun bentuk penanaman modal asing menurut Undang-undang nomor 1 tahun 1967 dapat berupa :

1. Penyertaan modal dasar secara langsung

2. Pemberian pinjaman luar negeri

3. Alat-alat perlengkapan perusahaan (industrial property).
Lisensi merupakan suatu terobosan bisnis terhadap ketentuan penaraman modal asing di Lndonesia yang cimaksudkan untiuk dapat meningkatkan perekonomian nastonal dart mentunjang penctpaian tujuan permbangunan nasionat.
Dengan demikian dapat dikatakan bahwa licensor sebagai investor turut menanamkan modal dalam suatu usaha lisensi. Adapun bentuk penanaman modal tersebut dapat berupa pemberian lisensi terhadap nama merek dagang atau paten yang dimilikinya, sehingga usaha lisensi ini dapat dikatagorikan sebagai suatu penyertaan modal secara informal yang sama artinya sebagai suatu terobosan bisnis terhadap ketentuan PMA. Intellectual property rights diakui oleh Undang-undang PMA sebagai salah satu bentuk modal asing yaitu termasuk dalam kategori penemuan-penemuan baru 
milik orang asing dan bahan-bahan yang dimasukkan dari luar negeri ke dalam wilayah Indonesia.

Suatu terobosan bisnis yang dilakukan dengan sistem lisensi tidak lain dimaksudkan untuk dapat menunjang dan meningkatkan perekonomian Indonesia yang nantinya dapat menambah penerimaan devisa bagi negara untuk meningkatkan dan mempercepat tercapainya tujuan pembangunan nasional.

Seperti telah diketahui bahwa perjanjian lisensi diadakan dengan pembayaran imbalan tertentu atau yang disebut dengan royalty, tentu akan menjadi persoalan berapa besarnya imbalan itu. Untuk dapat memperhitungkan berapa besarnya imbalan ini perlu diketahui beberapa faktor yang dapat digunakan sebagai dasar dalam menghitung imbalan untuk lisensi tersebut (Roeslan Saleh, 1991:23). Pada masa sekarang ini, merek dapat merupakan satu alat yang efektif untuk memperluas pasar, oleh karena itu mengingat fungsi merek yang sangat strategis (terutama untuk hasil produksi yang sudah terkenal) terdapat upaya untuk memanfaatkan secara optimal (Sri Rejek Hartono, Makalah Seminar, 1991:2).

Merek-merek internasional yang ada di Indonesia hadir dengan berbagai cara, salah satu cara adalah dengan memperkenalkan sistem lisensi yang merupakan strategi bisnis yang cukup menguntungkan. Keuntungan yang diperoleh oleh pemilik lisensi ini (licensor) adalah memperoleh pembayaran dari penjualan lisensi atau bagian keuntungan jika

\section{lihara suatu jaringan distribusi yang luas.}

Menanamkan modal secara langsung mempunyai resiko yang besar, sistem lisensi merupakan perbaikan dari sistem penanaman modal secara langsung. Lisensi ini berguna untuk memperkecil kekurangan modal yaitu dengan cara menjual lisensi produknya kepada pihak lain yang berminat. Dalam lisensi dipergunakan suatu standart tertentu untuk menjamin bahwa produk yang dihasilkan di manapun mempunyai mutu yang sama, pangsa pasarnya lebih jelas karena masyarakat modern pada umumnya tidak menyukai kejutan dan lebih cenderung menyukai produk yang bermerek yang sudah terkenal sebelumnya, hal inilah yang dimanfaatkan oleh lisensi.

Dengan menggunakan sistem lisensi, produsen memperoleh standart yang sama dalam setiap produk yang dihasilkan, baik jenis maupun mutunya, para investor sebagai penerima lisensi juga dapat menguasai dan mengembangkan teknologi dari produk tersebut. Dengan produk yang sama dan kemungkinan pengembangan teknologinya, maka konsumen tidak akan ragu lagi dalam membeli produknya. Hal inilah yang mendorong para investor lokal maupun dari luar 
negeri untuk menanamkan modalnya pada groduk-produk yang mempunyai merek terkenal melalui sistem lisensi.

B. Perjanjian lisensi merek

Perkembangan yang terjadi dalam prak-

terdapat beberapa

bentuk perjanjian lisensi merek, antara lain:

2. Eksklusif/non eksklusif

Dalam perjanjian lisensi merek disini, licensor disamping sebagai pemilik merek produksi obatobatan juga memiliki pengetahuan akan teknis/proses produksi dari obat-obatan tersebut, dan Perusahaan sebagai penerima lisensi (licensee) haruslah melaksanakan sendiri proses produksinya, dengan mendasarkan pada ketentuanketentuan yang telah ditetapkan oleh licensor dalam perjanjian.

Adapun lisensi merek yang diberikan dapat bersifat bersifat ekslusif, artinya bahwa pihak licensor tidak boleh melisensikan lagi merek produknya kepada licensee lain yang juga berkedudukan di Indonesia. Ini berarti bahwa hanya Licensee itulah sebagai satu-satunya pihak yang berhak untuk memproduksi obatobatan dengan merek milik lisensor untuk wilayah teritorial Indonesia.

Dalam perjanjian lisensi yang bersifat ekslusif ini terdapat pula ketentuan mengenai masih dimungkinkannya pihak licensor untuk mengubah sifat ekslusif menjadi non ekslusif yang berarti bahwa pihak licensor boleh melisensikan lagi merek produksinya kepada licensee lain yang juga berkedudukan di Indonesia. b. Sub lisensi / non sub lisensi

Pihak licensee kadang juga diberikan hak untuk men-sub lisensikan lisensi yang telah diterimanya dari licensor, dimana hak pemberian sub lisensi oleh license kepada pihak lain haruslah seijin / sepengetahuan dari pihak licensor.

Licensee juga bertanggung jawab kepada pihak licensor untuk membayar royalty atas barang-barang yang diproduksi dan dijual oleh penerima sublisensi, seolah-olah barang tersebut diproduksi dan dijual sendiri oleh licensee. Segala informasi yang diberikan oleh pihak licensor untuk keperluan proses produksi harus dijaga kerahasiaannya, tetapi dimungkinkan untuk diberikan kepada pihak penerima sub-lisensi dengan ketentuan bahwa penerima sublisensi wajib menjaga kerahasiaan tersebut. Dalam hal pengakhiran perjanjian sub-lisensi harus diadakan sekurang- 
kurangnya satu hari sebelum waktu pengakhiran perjanjian lisensi induknya.

c. Jangka waktu

Perjanjian lisensi merek ini berlaku sebagai kekuatan yang mengikat bagi para pihak didalamnya yang mengadakan perjanjian. Kekuatan masa berlakunya perjanjian lisensi merek diserahkan kedua belah pihak.

Pada waktu akan diadakan perpanjangan masa berlakunya perjanjian tersebut dapat diadakan perubahan/ penambahan mengenai isi perjanjian tersebut untuk dituangkan dalam perjanjian yang baru, dengan ketentuan bahwa hal tersebut harus dibicarakan lebih dahulu antara para pihak dalam jangka waktu enam bulan sebelum berakhirnya perjanjian lisensi merek tersebut.

Walaupun jangka waktu perjanjian lisensi telah ditentukan masa berlakunya, namun ada beberapa hal tertentu yang dapat menjadi ketentuan/syarat bagi para pihak untuk dapat mengakhiri perjanjian lisensi dalam hal tidak terpenuhinya salah satu syarat dalam perjanjian oleh pihak lain.

Licensor berhak untuk mengakhiri perjanjian lisensi ini apabila :

- Licensee tidak memenuhi kewajiban untuk membayar royalty dalam jangka waktu yang telah ditentukan.

- Licensee tidak memenuhi salah satu ketentuan yang telah ditetapkan bersama dalam perjanjian lisensi ini (selain ketentuan mengenai royalty), meskipun telah ada pemberitahuan / peringatan tertulis dari licensor untuk hal tersebut. - Adanya perubahan dalam susunan ke- pemilikan dalam perusahaan milik licensee tanpa terlebih dahulu memberitahukan kepada licensor.

Sebaliknya licensee juga berhak untuk mengakhiri perjanjian lisensi tersebut, jika :

a. Licensor tidak memenuhi salah satu ketentuan yang telah ditetapkan bersama dalam perjanjian lisensi meskipun telah ada pemberitahuan/peringatan tertulis dari licensee untuk hal tersebut.

b. Adanya perubahan dalam susunan kepemilikan dalam perusahaan milik licensor tanpa terlebih dahulu memberitahukan kepada licensee.

Dalam hal telah berakhirnya perjanjian lisensi, licensee tidak lagi berhak untuk menggunakan proses produksi/ alat produksi yang telah diberikan oleh licensor seperti pada saat berlangsungnya perjanjian ini.

\section{Royalty Dalam Kaitannya Dengan Pem- berian lisensi}

Undang-Undang Merek no. 19 tahun 1992 tidak mengatur bagaimana cara-cara pembayaran atau batas maximum pembayaran imbalan dari adanya perjanjian lisensi merek. Dalam perjanjian lisensi pembayaran adalah suatu hal yang lumrah, karena salah satu syarat perjanjian lisensi adalah kewajiban bagi penerima lisensi untuk membayar imbalan kepada pemberi lisensi atas hak merek yang telah dialihkan kepadanya. Tetapi yang perlu dikaji adalah bagaimana cara pembayaran tersebut, berapa besarnya royalty yang harus dibayar dan bagaimana cara menghitungnya. Hal ini penting guna 
kelancaran dan pengembangan suatu usaha dengan sistem lisensi yang mana diharapkan dipat membantu perkembangan perekonomian Indonesia di bidang industri.

1. Macam-macam cara pembayaran lisensi.

Sistem pembayaran didalam perjanjian lisensi dikenal bermacam-macam cara. Brendan Fowlston menjelaskan dalam bukunya yang berjudul Understanding Commercial and Industrial Commercial, bahwa ada enam cara pembayaran di dalam perjanjian lisensi yaitu pembayaran sekaligus (lumpsum), biaya yang dibayar berdasarkan negosiasi, biaya tahunan, ongkos pilihan, transfer pricing serta royalty. Berikut akan dijelaskan satu persatu yaitu :

a. Pembayaran sekaligus (lumpsum)

Pembayaran lisensi dapat dilakukan sekaligus didalam suatu perjanjian lisensi, dan biasanya pembayaran dilakukan pada saat penandatangan perjanjian. Disini penerima lisensi mempunyai resiko yang tinggi, sebab penerima lisensi harus menanggung kerugian sepenuhnya bila produk lisensi mengalami kegagalan, pemberi lisensi tidak

lagi bertanggung jawab terhadap produk barang yang dilisensikan. Sedangkan bagi pemberi lisensi cara pembayaran ini sangat menguntung-

\section{Menturtt Brendan Fowlston} pembayaran lisensi dapat ditempuh melalui cara-cara penbayaran sekaligus (Limpsam), biaya yang dibayar berdasarkin negosingi, biays tahunan, ongkes pithant trinsfer pricing atat priding royalt. kannya, karena ia telah tahu dengan pasti berapa yang ia dapatkan, tidak tergantung pada pro-sentase omzet penjualan yang belum pasti. Disamping itu juga jelas telah ada pembayaran atas hak mereknya yang dialihkan itu. Ia tidak lagi harus menanggung resiko bahwa penerima lisensi tidak akan membayarnya.

Pertimbangan dalam menghitung suatu jumlah lumpsum adalah sebagai berikut:

1. Biaya untuk mentransfer merek / paten, termasuk keahlian, informasi, teknis dan bantuan teknis.

2. Nilai dari pemberian merek/paten menurut penghitungan pemilik merek/paten.

3. Pertambahan keuntungan bagi penerima lisensi akibat memperoleh merek/paten berikut modifikasinya.

b. Biaya berdasarkan negosiasi

Menurut Brendaan Fowlston Pembayaran ini hanya dapat dilakukan jika dalam negosiasi si pemberi lisensi benar-benar berada dalam posisi yang kuat. Pembayaran ini umum dilakukan di Jepang, dan AS, tetapi tidak umum dilakukan di Eropa. Inti dari pembayaran ini adalah bila negosiasi tidak berhasil maka pemberi lisensi penerimaannya akan berkurang. Dengan 
demikian pemberi lisensi harus mengetahui tingkat kebonafiditasan penerima lisensi sehingga tidak akan mendatangkan kerugian baginya. Dalam hal ini masih dimungkinkan negosiasi antara para pihak, sehingga apabila produksi selanjutnya mengalami keberhasilan maka kepada pemberi lisensi akan diserahkan penggantian sejumlah royalty sebagai pengganti royalty yang berkurang pada waktu kegagalan hasil produksi yang terdahulu.

c. Biaya tahunan

Kadang-kadang suatu pembayaran lisensi dimana telah ditentukan untuk di-bayar dengan cara lampsum, namun dalam pelaksanaannya ternyata dibayar dengan cicilan. Hal ini biasanya karena terjadi suatu hal, misalnya karena kegagalan produksi. Untuk pembayaran lisensi yang diundurkan ini maka pemberi lisensi akan menerima sejumlah uang yang dimaksudkan sebagai pengganti kerugiannya, yang dibayarkan pertahun. Dalam pembayaran berupa cicilan ini pemberi lisensi akan menggunakan tehnik "discounted cash flow" dalam memperhitungkan harga dari pembayaran yang diundurkan.

Maksud dari discounted cash flow disini adalah Apabila pembayaran dilakukan lebih cepat dari pada waktu yang diperjanjikan, maka dapat diadakan suatu pengurangan bunga yang telah ditetapkan, disamping itu terdapat pula ketentuan yang mengharuskan penerima lisensi membayar suatu bunga denda yang diakibatkan karena pembayaran biaya tahunan itu terlambat dilakukan.

\section{d. Biaya pilihan}

Kadang-kadang calon penerima lisensi akan mempertimbangkan dahulu apakah ia akan menerima merek/paten yang ditawarkan kepadanya atau tidak. Untuk itu dibuatlah suatu perjanjian yang disebut "option agreement" sebelum ia memutuskan apakah akan menerima tawaran atau tidak.

Selama masa perjanjian itu, pemberi lisensi tidak boleh menyerahkan merek yang dimilikinya kepada pihak lain, selain calon penerima lisensi yang melakukan "option agreement" itu. Untuk itu maka pemberi lisensi akan menerima sejumlah pembayaran selama masa berlakunya perjanjian tersebut sampai saat habis waktunya atau si penerima lisensi telah memutuskan apakah akan menerima lisensi atau tidak.

e. Transfer pricing

Pembayaran ini sering menimbulkan pertanyaan, apakah hal ini merupakan metode yang sah atau tidak, dimana pemberi lisensi diperkenankan untuk mendapatkan kembali uangnya dibawah perjanjian lisensi. Praktek-praktek pembayaran ini sering dijumpai di beberapa negara. Maksud dari pembayaran ini adalah bahwa selama waktu perjanjian lisensi, pemberi lisensi menyediakan bahan mentah, komponen-komponen yang 
diperlukan dalam berproduksi, dan sebagainya, dimana penerima lisensi diwajibkan membelinya dari penerima lisensi, suatu premi akan dibayar oleh penerima lisensi, yang besarnya seharga royalty yang dibayarkan pada pemberi lisensi.

\section{f. Royalty}

Pembayaran lisensi yang berupa royalty biasanya dikaitkan dengan suatu bagian dari penjualan produk (turn oven) sehingga langsung merupakan biaya yang nyata diatas biaya produksi pabrik.

Pembayaran berupa royalty ini adalah paling umum diperjanjian antara para pihak dalam perjanjian lisensi merek, karena kedua pihak baik pem-beri maupun penerima lisensi mempunyai resiko yang sebanding.

Menurut UU No.10 tahun 1970 tentang pajak atas Bunga, Deviden dan Royalty dalam pasal 3e dijelaskan bahwa Royalty adalah hasil yang diterima sebagai balas jasa untuk :

a) Menggunakan atau hak menggunakan paten/oktroi, merek dagang, pola atau model, rencana, rahasia perusahaan, cara mengerjakan, hak mengarang dan hak cipta mengenai sesuatu karya di bidang kesusasteraan, kesenian atau ilmiah, termasuk karya film sinematografi. b) Menggunakan atau hak menggunakan alat-alat perlengkapan perindustrian, perniagaan dan ilmu pengetahuan.

c) Mendapatkan bahan-bahan dan informasi yang diperlukan mengenai usaha dan investasi pada umumnya, pengalaman dibidang industri, perniagaan dan ilmu pengetahuan pada khususnya.

Jadi royalty itu mencakup tiga pengertian yaitu:

1) Balas jasa untuk menggunakan atau hak menggunakan intellectual property rights.

2) Balas jasa untuk mengunakan atau hak menggunakan equipment, baik di bidang industri, komersial atau ilmu pengetahuan.

3) Balas jasa untuk menggunakan keahlian (know how).

Menurut Amir Pamuntjak dalam makalahnya yang berjudul Ketentuan Royalty Di dalam Persetujuan Perlisensian menjelaskan bahwa Royalty sebagai salah satu cara dalam melakukan pembayaran lisensi dapat dijumpai dalam tiga bentuk, yaitu royalty berjalan (running royalty), royalty minimum tahunan dan royalty bayar penuh (paid up).

Ketiga bentuk royalty tersebut diatas masing-masing berbeda di- 
dalam penetapan pembayarannya, seperti yang akan dibahas berikut ini :

a. Royalty berjalan (running royalty)

Yang dimaksud dengan royalty berjalan adalah bentuk pembayaran royalty dimana tarif royalty dikalikan dasar royalty. Tarif royalty diungkapkan dalam prosentase tertentu, sedangkan dasar royalty dapat berbentuk unit produksi, penjualan atau laba tersebut diatas. Dasar royalty yang paling sering dijumpai adalah nilai bersih penjualan yang pada prinsipnya berarti harga jual produk yang dihasilkan dibawah lisensi dikurangi dengan pajak penjualan, rabat dan potongan lainnya. Jika royalty ditetapkan nilai tertentu untuk seluruh perjanjian dinamakan royalty tarif tetap (fixed royalty rate), sedangkan tarif royalty yang selalu berubah selama masa perjanjian biasa disebut royalty tidak tetap, misalnya roylaty ditetapkan sebagai berikut :

- $5 \%$ dari nilai bersih penjualan

sebagai salah satu cara dahan pembayatan lisersi, royalty dapat ditumpat defam 3 bentri, yaith roynty berjathr (numing roysity). rojalty minimum dan noyaly bayar penuh (paid up). sampai dengan Rp. 100 juta setahun, atau

- $4 \%$ dari nilai bersih penjualan lebih dari Rp. 100 juta tetapi kurang dari 300 juta setahun, atau

- $3 \%$ dari nilai bersih penjualan di atas Rp. 300 juta setahun.

b. Royalty minimum tahunan Suatu pembayaran royalty tahunan yang minimal adalah untuk menjamin agar si pemegang lisensi akan memelihara suatu tingkat produksi yang minimal. Hal ini biasanya terjadi dalam praktek menyangkut perjanjian lisensi ekslusif, yaitu perjanjian dimana pihak pemberi lisensi tidak boleh mengadakan perjanjian lisensi yang sama dengan pihak ke tiga di wilayah negara yang diperjanjikan. Dalam royalty minimum tahunan ini jika penerima lisensi gagal memenuhinya maka mungkin akan mengakibatkan hilangnya eksklusifitas. Dalam kebanyakan hal, untuk tahun pertama setelah diadakannya perjanjian lisensi tidak dikenakan persyaratan royalty minimum, tetapi mungkin hanya dikenakan royalty minimum yang sangat rendah, dengan maksud agar tarif royalty minimum tahunan itu akan dapat dinaikkan nanti apabila produski penuh telah tercapai.

c. Royalty bayar penuh (paid up) 
Ongkos royalty bayar penuh adalah royalty total yang harus dibayar selama periode kontrak. Mengenai paid up ini seringkali juga yang dimaksudkan adalah suatu pembayaran sekaligus yang kemudian disusul oleh pembayaran-pembayaran dengan jumlah tetap atau persentase-persentase tertentu.

D. Permasalahan Yang Timbul Dalam Pemberian Lisensi Merek

Masalah-masalah yang dapat timbul bungan dengan pemberian lisensi merek at berupa persaingan curang dan perisihan dalam pelaksanaan isi perjanjian. Persaingan curang.

Perkara-perkara merek yang terjadi pada waktu berlakunya Undang-undang No. 21 tahun 1961 tentang merek perusahaan dan perniagaan pada umumnya disebabkan karena sistem pengakuan merek yang berlaku pada waktu itu dimana pemakai pertama suatu merek dianggap sebagai pemilik merek yang berhak. Sistem ini sering menimbulkan masalah karena terdapat kesulitan dalam membuktikan siapa pemakai pertama suatu merek. Disamping itu tidak diaturnya ketentuan mengenai lisensi menyebabkan keberadaan lisensi tidak diakui, meskipun dalam praktek perdagangan telah sering digunakan. Hal ini dapat sebagai penyebab timbulnya masalah-masalah persaingan curang dalam lisensi merek, dimana tidak dapat didaftarkannya sistem lisensi pada Kantor Merek (dulu Direktorat Paten dan Hak Cipta) dapat memudahkan orang lain dengan leluasa meniru merek yang dilisensikan pada seseorang.

Adapun perwujudan persaingan curang dalam lisensi merek dapat dicontohkan sebagai berikut :

Adanya suatu peniruan/pemalsuan yang dilakukan oleh pihak ketiga terhadap suatu merek milik seseorang yang didapatkan atau dimilikinya dari adanya perjanjian lisensi. Misalnya pihak licensor dan licensee mengadakan suatu perjanjian lisensi merek, dimana licensee diizinkan memproduksi suatu barang dengan menggunakan merek milik licensor dan karena sistem lisensi tidak diatur dan tidak bisa didaftarkan pada Kantor Merek (dulu Direktorat Paten dan Hak Cipta) maka hal ini dijadikan kesempatan bagi pihak ketiga untuk mengadakan pemalsuan/membonceng terhadap merekmerek terkenal tersebut dan memakai merek tersebut atas nama milik pihak ketiga tersebut.

Ketentuan pidana atau sanksi-sanksi dari adanya pelanggaran dibidang merek
Pemmasalahan yang kerap kafl mumcul

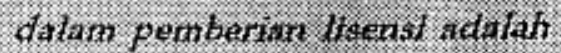
menyangkwt persiangun curtang dan partikaim dalmm melatsmakan ist perjantan isersst. tidak diatur dalam Undang-undang Merek No. 21 tahun 1961. Perkara-perkara merek yang terjadi pada waktu itu proses penun- 
tutannya hanya mendasarkan pada ketentuan pasal 1365 Kitab Undangundang Hukum Perdata dan pasal 382 bis Kitab Undang-undang Hukum Pidana, yaitu sebagai perbuatan melawan hukum dan sebagai perbuatan yang menyesatkan khalayak ramai.

Setelah berlakunya Undang-undang Merek No. 19 tahun 1992, masalah pelanggaran di bidang merek diatur secara tegas pada pasal 81 dan 82 , disamping dapat dilakukan tuntutan ganti rugi juga dikualifikasikan sebagai tindak pidana pemalsuan dan persaingan curang. Hal ini menunjukkan bahwa pasal tersebut memberikan jaminan kepastian hukum dalam masalah persaingan curang. Konsekuensi jaminan kepastian hukum ini adalah bahwa pelaku persaingan curang dapat dituntut dimuka Pengadilan dengan dasar pasal 81 dan 82 UU No. 19 tahun 1992 tersebut.

2. Perselisihan dalam pelaksanaan isi perjanjian. Suatu perjanjian yang dibuat oleh para pihak walaupun sudah disepakati kadangkala tidaklah selalu dapat berjalan mulus, adakalanya terdapat perselisihan dalam pelaksanaan isi perjanjian antara kedua belah pihak, sebagai contoh salah satu pihak dalam perjanjian melakukan wanprestasi.

Dalam hal terjadi perselisihan dalam pelaksanaan isi perjanjian, bagaimanakah cara penyelesai-
Satclah berlakunya UU 19 / 92, masalah persaingan curang dalam perjanjian insensi penyetesalannya dapat ditempath nielaliti pengadilan baik dengan gugatan perdata ataupun tuntutan pidana. Sedangkan perselisitian dakarn atelaksanakan isi perjantian dapat ditemptih mutatui stbitrase. annya, apakah melalui suatu badan Pengadilan tertentu yang ditunjuk atau melalui suatu badan diluar Pengadilan (arbitrase). Hal tersebut merupakan masalah yang harus dikaji dalam perjanjian lisensi.

Penyelesaian perselisihan dalam pelaksanaan isi perjanjian lisensi yang sering digunakan adalah melalui arbitrase, karena dengan melalui arbitrase proses penyelesaian sengketa dapat dilaksanakan dengan cepat dan praktis juga lebih dapat sesuai dengan perasaan keadilan para pihak. Karena para arbitator terdiri dari orang ahli dalam bidang yang dipersengketakan, yang diharapkan mampu membuat putusan yang memuaskan para pihak, disamping itu putusan arbitrase tersebut dirahasiakan, sehingga masyarakat umum tidak mengetahui tentang kelemahan-kelemahan perusahaan yang bersangkutan. Sifat rahasia pada putusan arbitrase inilah yang dikehendaki oleh para pihak.

Adapun yang dimaksud dengan Arbitrase atau Perwasitan menurut H.M.N. Purwosutjipto dalam bukunya yang berjudul Pengertian Pokok Hukum Dagang Indonesia bagian kedelapan, arbitrase adalah suatu peradilan perdamaian, dimana para pihak bersepakat agar perselisihan mereka tentang hak pribadi yang dapat mereka kuasai sepenuhnya diperiksa dan diadili oleh hakim yang ti- 
dak memihak, yang ditunjuk oleh para pihak sendiri dan putusannya mengikat bagi kedua belah pihak.

Dalam penyelesaian perselisihan melalui arbitrase disini, disamping ditentukan tentang arbriternya, pihak licensee dan licensor disini juga menetapkan ketentuan tentang siapa yang menanggung biaya arbitrase tersebut, yaitu diperjanjikan bahwa biaya arbitrase dibagi sama rata antara kedua belah pihak. Dan juga ditetapkan bahwa putusan arbitrase tersebut mengikat kedua belah pihak, dan bersifat final.

\section{E Catatan Akhir}

Lisensi merek sebagai salah satu terobosan is berskala internasional perlu untuk terus embangkan. Selain berperanan dalam perlancar bisnis skala internasional dan opang kehidupan badan usaha, berbangnya sistem lisensi merek akan dapat gurangi pembajakan merek-merek terkenal.

\section{AFTAR PUSTAKA}

Cornish, 1981, Intellectual Propertty Right, Paten, Copy Rights, Trade Mark and Allied Right, London, Sweet and Maxwell

Emmawaty Yunus,1992, Laporan Seminar Industrial Property System, Dirjen Paten Paten \& Hak Cipta Depkeh

Fartono Adisumarto, 1989, Hak Milik Intelektual khususnya Paten \& Merek, lakarta, Akademika Presindo
HMN Purwosutjipto, 1988, Pengertian Pokok Hukum Dagang Indonesia buku 8, Jakarta, Djambatan

Keith Hodkinson, 1987, Protecting and Exploiting New Technology and Design, London, $\mathrm{F}$ and $\mathrm{N}$ Spon

NA Sutijarto,1981, Hukum Milik Perindustrian, Yogyakarta, Liberty

Sri Rejeki Hartono, 1992. Makalah Seminar di UMK Kudus

Sudargo Gautama,1990, Segi-Segi Hukum Hak Milik Intelektual, Bandung, Eresco

Alumni

1992, UU Merek, Bandung,

Indonesia,Bandung,

Citra Aditya Bhakti

Soegondo Soemodirjo, 1963, Merek Perusahaan dan Perniagaan,Jakarta, LAN.

Soekardono, 1983,Hukum Dagang Indonesia, Jakarta, Dian Rakyat

WIPO,1980, Model Law For Developing Countries on Invention, Geneva, Vol. II

UU no. 1 tahun 1967 tentang PMA

UU no. 6 tahun 1989 tentang Paten

UU no. 19 tahun 1992 tentang Merek Kitab Undang-Undang Hukum Perdata 